\title{
STUDY OF BODY IMAGE IN PROFESSIONAL DANCERS: A SYSTEMATIC REVIEW
}

\author{
ESTUDO DA IMAGEM CORPORAL EM BAILARINOS PROFISSIONAIS: UMAREVISÃOSISTEMÁTICA
}

Systematic Review Article

ARtIGO de REVISÃo SISTEMÁtICA Artículo de Revisión Sistemática
Allana Alexandre Cardoso'

(Profissional de Educação Física)

Nycolle Martins Reis ${ }^{1}$

(Profissional de Educação Física)

Ana Paula Marinho'

(Fisioterapeuta)

Leonessa Boing

(Profissional de Educação Física)

Adriana Coutinho de Azevedo

Guimarães ${ }^{1}$

(Profissional de Educação Física)

1. Universidade do Estado de Santa Catarina (UDESC), Centro de Ciências da Saúde e do Esporte (CEFID), Programa de Pós-Graduação em Ciências do Movimento Humano (PPGCMH), Florianópolis, Santa Catarina, Brazil.

\section{Correspondence:}

Allana Alexandre Cardoso Universidade do Estado de Santa Catarina, Centro de Ciências da Saúde e do Esporte (UDESC/CEFID).

Rua Pascoal Simone, 358, Coqueiros, Florianópolis, SC, Brazil. 88080-350. allana.alexandre@gmail.com

\begin{abstract}
Body image is multidimensional, dynamic, and entirely linked to the body in motion, which entails relevant bodily concerns in the routine of professional dancers, who need to maintain their body aesthetics constantly. The objective was summarizing the scientific production on the body image of professional dancers and to understand how they perceive it. This review is composed by seven studies that investigated professional dancers of classical ballet, jazz and contemporary dance. The results demonstrate that even though they are lean and had appropriate body mass index, professional dancers are dissatisfied with their body and wish to be thinner, that is, professional dancers constitute a risk group for the development of eating disorders.
\end{abstract}

Keywords: dancing; body image; feeding and eating disorders.

\section{RESUMO}

A imagem corporal é multidimensional, dinâmica e totalmente vinculada ao corpo em movimento, o que acarreta preocupações corporais relevantes na rotina de bailarinos profissionais, que precisam manter a estética corporal constantemente. Objetivou-se resumir a produção científica sobre a imagem corporal de bailarinos profissionais e compreender como eles a percebem. Esta revisão écomposta por sete estudos que investigaram bailarinos profissionais das modalidades de balé clássico, jazz e dança contemporânea. Os resultados demonstram que, mesmo sendo magros e tendo índice de massa corporal adequado, os bailarinos profissionais estão insatisfeitos com seu corpo e desejam ser mais magros, ou seja, bailarinos profissionais constituem um grupo de risco de desenvolvimento de transtornos alimentares.

Descritores: dança; imagem corporal; transtornos da alimentação e da ingestão de alimentos.

\section{RESUMEN}

La imagen corporal es multidimensional, dinámica y totalmente vinculada al cuerpo en movimiento, lo que acarrea preocupaciones corporales relevantes en la rutina de bailarines profesionales, que necesitan mantener la estética corporal constantemente. El objetivo fue resumir la producción cientifica sobre la imagen corporal de bailarines profesionales y comprender cómo la perciben. Esta revisión está compuesta por siete estudios de investigación de bailarines profesionales de las modalidades de ballet clásico, jazzy danza contemporánea. Los resultados demuestran que, aunque sean delgados y tengan un índice de masa corporal adecuado, los bailarines profesionales no están satisfechos con su cuerpo y desean ser más delgados, es decir, bailarines profesionales constituyen un grupo de riesgo para el desarrollo de trastornos alimentarios.

Descriptores: baile; imagen corporal; trastornos de alimentación y de la ingestión de alimentos.

\section{INTRODUCTION}

The body image its a human body picture built on the mind, considering its constituent parts and the feelings related to those ${ }^{1,2}$. Influenced by intrinsic aspects of the individual, like age and sex; extrinsic, values and belief ${ }^{1,3}$; social aspects, as relatives and friends perception ${ }^{4}$; as well cognitive and affective factors related to the corporal experiences ${ }^{5}$, is seen as a multidimensional phenomenon, highly dynamic and fully linked to the moving body ${ }^{6}$.

Under the moving body continuous focus, body concerns are extremely common among dancers ${ }^{7}$, since, occupations that demands a suitable body esthetics, like models, dancers and athletes, presents greater incidence at the body dissatisfaction cases $^{8}$. Some studies show that, when the subjects are professional dancers, the esthetics pattern maintenance demand is even higher when compared to the general population ${ }^{9-12}$.
The search of preservation for an excellent physical quality becomes a basic need, making these dancers try even harder to balance physical fitness, strength, beauty patterns, softness and dramatics expressions, inherent characteristics to the dance performance ${ }^{13-16}$. The importance of this study is justified, since, the pressure to achieve the ideal patterns can bring the body image distortion, Always tending to a quest for an even thinner body 9,10,17, mostly in classical ballet, that many times enforces the thinness beyond the normal and healthy limits ${ }^{15,18}$. However, despite the undeniable relevance of this thematic, after an extensive search realized in the specialized literature was identified the absence of review studies about the subject, mainly those that allow identifying specific closure segments to the professional activities of these dancers. In face of the exhibited, this systematic review objective was apart from of summarize the scientific production about the body image of professional dancers, comprehend how this subjects see their body image. 


\section{METHODS}

This systematic review was accredited under the number CRD42015029631 in the International Prospective Register Of Systematic Reviews- PROSPERO and follows the proposed recommendations by the Preferred Reporting Items for Systematic Review and Meta-analyses: The PRISMA Statement ${ }^{19}$. The guiding questions were formed by the way of the acromion PICOS, that characterize the three main endings of this review, they are, the summarization of the scientific production about the body image of professional dancers, the identification of the instruments that evaluate these dancers'body image and, based on that, verify how the professional dancers see their body image.

\section{Eligibility criteria}

Were included observational cohort studies, transversal and control case, that brings the body image thematic in professional dancers, indexed on previously selected databases, with available abstracts, that were fully accessed on-line, published in Portuguese, English or Spanish. Due the lack of publication on the investigated thematic, the search was not restricted to the last decade, might be included published articles in all periods. Were yet included, articles identified by the way of manual search in the references of identified articles in the database. Weren't considered eligible to review, methodologic characterized studies as systematic reviews or literature, pilot studies, case study, studies protocols, dissertations, theses, book chapters, special insert section or editor comments as well the identified articles as cross references.

\section{Search strategy}

To the search strategy were selected the electronic databases BIREME, LILACS; MEDLINE (Medical Literature Analysis and Retrieval System on-line) Complete (EBSCO);WEB OF SCIENCE - Main collection (Thomson Reuters Scientific); SCOPUS (Elsevier) e PubMed. The descriptors, proposed in the Medical Subject Headings (MeSH) e DeCS (Health science descriptors) referred to body image: "body image" and the population: "dancing". In addition, the MeSH terms were used key words found in the articles previously obtained, named "professional dancers". All the search strategies were developed in november 2015.

\section{Studies and data extraction selection}

As the studies and data extraction selection, beside the main researcher, two independent reviewers realized the search in the selected database. First was realize the articles title reading, then the abstract read and finally the full article. In the divergence cases among selected articles by the reviewers, all members repeated the procedures until the discrepancies were correct. Subsequently to the article selection, they were submitted to a qualitative and quantitative analyses and the obtained information were: author(s) and publish year, title, study location, study section, investigated population (total, sex and age, periodic and qualis/fator of impact (Table 1); study identification studies details, objectives, used instruments, main results and methodologic quality evaluation results (Table 2).

\section{Methodologic evaluation}

The quality of each included study was evaluated independently by the reviewers from the methodologic criteria proposed by Downs and Black ${ }^{20}$, that consists in 27 questions that cover methodologic aspects of communication, external validity, internal validity (bias), internal validity (confusion factors) and statistic power. To the appreciation of the studies that not included in its methodology interventions and clinic cases studies, in order to fill the criteria established to the selected observational studies to form this review, 15 questions were consider, excluding 4, 8, $13,15,17,19,21,24$ and 26 questions. For each question was applied the zero score, if the article was not pertinent to what is evaluating and the score one (1) when a positive answer to the requisite is observed, and just question 5 has max 2 score. With that, the max score of each article was 16 points, related to the following criteria: a) hypothetic or objectives; b) main endings; c) included participants characteristics; d) distribution of the main confusion variables; e) main result description; f) information about aleatory variability estimative on data for the main endings; g) information about sampling losses characteristics; $h$ ) information about probability values; i) selected individuals representative; j) included individuals representative; $\mathrm{k}$ ) results clearness to non stablished hypothetic; I) adequacy of the used statistics tests; $m$ ) if the used measures to the main endings were accurate; $n$ ) if the analyses included an adequate adjustment to the main confusion variables; o) if the study had enough power to detect an important effect with a significance level of $95 \%$.

\section{RESULTS}

The search allowed to identify 32 articles that had their bibliography references manually evaluated what allowed add one more study, numbering 33 articles. After the general evaluation were excluded 16 studies that shown by titles and abstracts that did not cover the eligibility criteria. The detailed evaluation pointed that eleven studies did not cover the thematic in the required population. This way, seven were consider potentially relevant and were included in this review (Figure 1).

The main methodological characteristics of the seven included studies in this review are presented in the Table 1, naming author/year, title, study localization, study section, population/sex/age average, periodic and qualis where it was publish 10,15,17,21-24. The findings show that the major number of publications happens between 2009 and 2014, and just one of the articles was publish in 1998. Just three articles specified the adopted methodology, and these published in Portuguese and belonging to the "Revista Brasileira de Medicina do Esporte" - qualis A2, predominant periodic in this review. The four studies published in English,

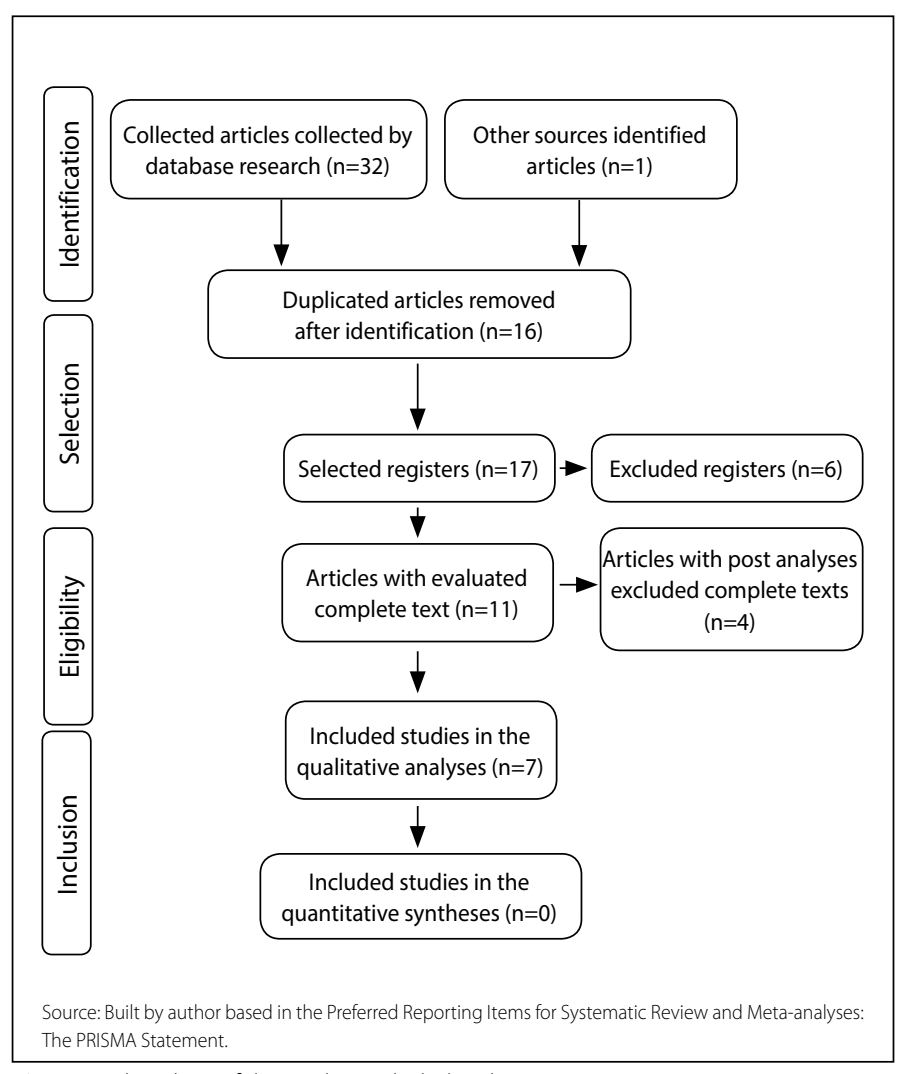

Figure 1. Flowchart of the studies included in the review. 
Table 1. Main characteristics of the studies.

\begin{tabular}{|c|c|c|c|c|c|c|c|}
\hline & $\begin{array}{l}\text { Author/ } \\
\text { year }\end{array}$ & Title & $\begin{array}{l}\text { Local of } \\
\text { study }\end{array}$ & Study section & $\begin{array}{c}\text { Population } \\
\text { ( } n \text {, sex and average age) }\end{array}$ & Periodic & $\begin{array}{c}\text { Qualis/ } \\
\text { impact factor }\end{array}$ \\
\hline 1 & Simas et al. $2014^{15}$ & $\begin{array}{c}\text { Body image and its relation with weight } \\
\text { and body mass index in professional } \\
\text { dancers. }\end{array}$ & Brazil & $\begin{array}{l}\text { Descriptive } \\
\text { comparative }\end{array}$ & $\begin{array}{c}181 \mathrm{PD} \\
105 \text { classic, } 76 \text { contemporary } \\
54,1 \% \mathrm{~F} \mathrm{e} 45,9 \% \mathrm{M} \\
24,36 \pm 6,14 \text { years }\end{array}$ & $\begin{array}{c}\text { Rev Bras Med } \\
\text { Esporte }\end{array}$ & A2 \\
\hline 2 & Haas et al. ${ }^{10}, 2010$ & Body image of professional ballet dancers & $\begin{array}{l}\text { Brazil and } \\
\text { USA }\end{array}$ & $\begin{array}{l}\text { Descriptive field } \\
\text { research }\end{array}$ & $\begin{array}{l}15 \text { PD classics Brazilians; } \\
16 \text { PD de jazz Brazilians; } \\
9 \text { PD classics ingrained in } \\
\text { New York; }\end{array}$ & $\begin{array}{c}\text { Rev Bras Med } \\
\text { Esporte }\end{array}$ & $\mathrm{A} 2$ \\
\hline 4 & Pollatoua et al. ${ }^{21}, 2010$ & $\begin{array}{l}\text { Body image in female professional and } \\
\text { amateur dancers }\end{array}$ & Greece & $\mathrm{NI}$ & $\begin{array}{l}115 \text { PD e } 85 \text { amateurs } \\
\text { All female } \\
15 \text { and } 30 \text { years. }\end{array}$ & $\begin{array}{l}\text { Research } \\
\text { in Dance } \\
\text { Education }\end{array}$ & - \\
\hline 5 & Nascimento et al. ${ }^{22}, 2012$ & $\begin{array}{c}\text { Body dysmorphic disorder and eating } \\
\text { disorders in elite professional female } \\
\text { ballet dancers. }\end{array}$ & Brazil & $\mathrm{NI}$ & $\begin{array}{c}19 \mathrm{BP} \\
34.46 \pm 8.85 \text { years }\end{array}$ & $\begin{array}{l}\text { Ann Clin } \\
\text { Psychiatry }\end{array}$ & B1 \\
\hline 6 & $\begin{array}{l}\text { Zoletic and Durakovic- } \\
\text { Belko } 23,2009\end{array}$ & $\begin{array}{l}\text { Body image distortion, perfectionism and } \\
\text { eating disorder symptoms in risk group } \\
\text { of female ballet dancers and models and } \\
\text { in control group of female students. }\end{array}$ & Bosnia & $\mathrm{NI}$ & $\begin{array}{l}91 \text { participants } 13 \text { PD } 55 \\
\text { students CG and EG and } 23 \\
\text { Professional models }\end{array}$ & $\begin{array}{l}\text { Psychiatr } \\
\text { Danub }\end{array}$ & $\begin{array}{l}1.301 \\
(2015)\end{array}$ \\
\hline
\end{tabular}

*PD: professional dancers; CG: Control Group; EG experimental group; F: female; M: male; Nl: not informed. Source: Built by the Author.

one belongs to a Perceptual and Motor Skills Journal's - qualis A2; um a Ann ClinPsychiatry - qualis B1, an the other two periodic to a Research in Dance Education (2014 Impact per publication 0.388 - values from Scopus) and Psychiatria Danubina (indexed in some databases like Excerpta Medica (EMBASE), Psychological Abstracts/PsycINFO, Chemical Abstracts, MEDLINE/ PubMed, EBSCO, Current Contents - Social and Behavioral Sciences, and others), although the approach to the target thematic of this review do not have classification and impact factor on Physical Education area.

The Table 2 presents the objectives, the used instruments to the body image in professional dancers, the main results and the methodologic quality evaluation of the included studies on the review, by the way of the Downs and Black ${ }^{20}$ scale.

602 participants, 347 classical ballet professional dancers, 76 contemporary professional dancers and 16 jazz professional dancers, composed the full sample of this review, the other 163 are divided between amateur dancers, models, athletes and students. In conclusion, the studies included in the sample realized a comparative between professional dancers from different dance modalities (classical ballet, contemporary and jazz), and other yet compared professional dancers with amateur dancers, models, athletes and students. The selected studies proposed an investigation to the perception and the satisfaction level with the body image its variable, ending and its possible relation with the weight perception, body mass index, as well the probable association with neurotics symptoms of perfectionism and risk behavior to eating disorders in professional dancers of different modalities and others participants.

Different instruments were used to evaluate the perception of the body image in the participants, among them, the silhouette scale of Stunkard, being the most used one, studies 1, 3 and 715,17,24, followed by Body Shape Questionnaire used in the study 2 (HAAS; GARCIA; BERTOLETTI, 2010), the Multidimensional Body Self Relations Questionnaire in the study $4^{21}$, Beck Depression Inventory in study $5^{22}$, and the Body mass index-silhouette matching test in the study $6^{23}$

The nine silhouettes scale, proposed by Stunkard, used in three of the seven included studies in this review, presents nine silhouettes, to each gender, with different body sizes, enumerated from the smallest (thinner -1 ) to the bigger (fatter - 9). The evaluated one chose the number of the silhouette that it believes to be more alike to its real appearance and also choose the one that it believes to be the most similar to the considered ideal appearance to its age.

To the body satisfaction evaluation, the assigned score is deducted from the real body appearance from the ideal body appearance, may vary from -8 to +8 . If this variation is equal to zero the subject is classified as satisfied; if it is different to zero, the subject is classified as dissatisfied. If the difference is positive it is a dissatisfaction by overweight; and when it is negative, is a dissatisfaction by thinness. The scale is considered a valid measure $(r=0,72)$ of the body image in Brazilians ${ }^{25}$. 
Table 2. Objectives, instruments, main results and methodological quality evaluation of the included studies in the review.

\begin{tabular}{|c|c|c|c|c|}
\hline & Objectives & Used Intruments & Main results & $D \& B$ \\
\hline 1 & $\begin{array}{l}\text { Investigate the satisfaction with the Bl and the } \\
\text { relation with the weight perception and the BMI } \\
\text { in classic and contemporary Brazilian PD. }\end{array}$ & Stunkard silhouette scale & $\begin{array}{l}\text { The classic PD are mostly dissatisfied by overweight wishing } \\
\text { weight less, while the contemporary PDs, majorly, are satis- } \\
\text { fied with their BI and a significant group wish to gain weight, } \\
\text { specially males; the participants of both modalities have BMI } \\
\text { considered adequate, according the normality references with } \\
\text { a tendency to a lower limit. }\end{array}$ & 13 \\
\hline 2 & $\begin{array}{l}\text { Verify yhe satisfaction level with the BI of classi- } \\
\text { cal and jazz PD, identifying the disease similari- } \\
\text { ties between the two groups, making the same } \\
\text { analysis in the classical PD from other countries. }\end{array}$ & $\begin{array}{c}\text { Body Shape } \\
\text { Questionnaire (BSQ) }\end{array}$ & $\begin{array}{c}\text { The dancers, beside the chosen modality, present dissatisfac- } \\
\text { tion levels and BI distortion, without significate differences } \\
\text { among the three evaluate groups. }\end{array}$ & 13 \\
\hline 3 & $\begin{array}{l}\text { Evaluate the } \mathrm{BI} \text { perception and its association } \\
\text { with risk behavior to FD in PD. }\end{array}$ & $\begin{array}{l}\text { Stunkard Silhouette Scales; Eating } \\
\text { Attitudes Test (EAT-26); Bulimic } \\
\text { Investigatory Test Edinburgh (BITE); }\end{array}$ & $\begin{array}{l}\text { Was detected that } 50,8 \% \text { of the PD would like to have a smaller } \\
\text { silhouette than the actual one, the risk behavior presence of } \\
\text { FD was 2,71 times higher among those that wish to have a } \\
\text { silhouette smaller than the usual and 2,64 times higher among } \\
\text { those who wants to have a smaller silhouette, smaller than the } \\
\text { considered healthy, when compared to those satisfied with } \\
\text { their silhouette. }\end{array}$ & 14 \\
\hline 4 & $\begin{array}{l}\text { Investigate how the } \mathrm{BI} \text { can be affected in active } \\
\text { female dancers, professional and amateurs }\end{array}$ & $\begin{array}{l}\text { Multidimentional Body Self Rela- } \\
\text { tions Questionnaire (MBSRQ) }\end{array}$ & $\begin{array}{l}\text { The participant dance status was significantly associated with } \\
\text { three of ten subscales MBSRQ, com PD the higher average } \\
\text { scores were fitness oriented and areas of dissatisfaction, the } \\
\text { lower scores concerned with the overweight. }\end{array}$ & 10 \\
\hline 5 & $\begin{array}{l}\text { Report the prevalence and the clinical charac- } \\
\text { teristics associated with body shapeless distur- } \\
\text { bance and the FD in a Brazilian elite PD group. }\end{array}$ & $\begin{array}{l}\text { Mini International Neuropsychiat- } \\
\text { ric Interview; Bulimic Investigatory } \\
\text { Test Edinburgh (BITE); Beck Depres- } \\
\text { sion Inventory }\end{array}$ & $\begin{array}{l}15,78 \% \text { of the PD had the nervous anorexia diagnosis and } \\
10.52 \% \text { presents body shapeless disturbance; none of the } \\
\text { individuals had nervous bulimic actually or in any life moment; } \\
\text { the prevalence of body shapeless disturbance and FD among } \\
\text { female elite PD is higher when compared to the common } \\
\text { population. }\end{array}$ & 12 \\
\hline 6 & $\begin{array}{l}\text { Verify the relation between the Bl, perfectionism } \\
\text { neurotic symptoms and FD in a high-risk group, } \\
\text { models, PD and a students' PG. }\end{array}$ & $\begin{array}{l}\text { Body mass index-silhouette match- } \\
\text { ing test (BMI-SMT); Neurotic } \\
\text { perfectionism questionnaire (NPQ); } \\
\text { Eating Disorders Inventory (EDI) }\end{array}$ & $\begin{array}{c}\text { There is a difference in the BI distortion, neurotic perfectionism } \\
\text { and FD symptoms among PD, models and students, as well a } \\
\text { body overestimation related to their real objective dimensions; } \\
\text { The PD and models have a worst BI when compared to the } \\
\text { students, also presenting more FD symptoms. }\end{array}$ & 9 \\
\hline 7 & $\begin{array}{l}\text { Exam the BI perception among a elite PD group } \\
\text { and compare its perceptions with objective pat- } \\
\text { terns to body completion. }\end{array}$ & Stunkard Silhouette Scale & $\begin{array}{l}\text { BP can be in higher BI distortion risk when compared to others } \\
\text { athletes and common population; while the athletes with dif- } \\
\text { ferent body profiles can realize the success in a specific sport, } \\
\text { dancers need to reach a specific body completion regarded as } \\
\text { ideal to participate in elite teams. }\end{array}$ & 5 \\
\hline
\end{tabular}

*PD: professional dancers; Bl: body image; FD: food disorders; BMI: body mass index; D\&B: Methodologic quality evaluation Downs \& Black with max score of 15 points. Source: Built by the author.

Damasceno et al..$^{26}$, reports that the nine silhouette scale, proposed by Stunkard presents some limitations. The instrument does not allow the individual representation as one, because does not consider anthropometric aspects important in the individual body image formation, as the subcutaneous fat mass distribution. however when investigate the ideal physical type and satisfaction with the body image of Hiking practitioners using the Stunkard scale, the authors concluded that this scale shows effectiveness, presenting strong co-relations of Body mass index and fat percentage beside the identifications of the investigated individuals silhouette ${ }^{26}$.
Although it is not the golden pattern to the body image evaluation, the scale is considered an accessible instrument to researchers without private or government funding to their researches and many times can't have access to the radiologic absorptiometry of double energy (DEXA) that consists in one of the most precise quantitative methods to evaluate bone mass, thin mass and fat mass. However, this method was not used in any study included in this review, observed the lack of financial resources and the limitations to access it.

As the obtained score by the way of the methodologic scale Downs and Black ${ }^{20}$, the articles obtained 10, 86 as average considering the 
maximum score of 16 points. Among the methodologic criteria that present fails are: the non-description of the characteristics of the lost patients during the study; the lack of background definition of the results (non detail level of the main confusion factors) and the related aspects to the internal validity of the studies.

\section{DISCUSSION}

The professional dancers identity is built during the dancers carrier, and traces like pain resilience, discipline, perfectionism, aesthetic care, self judgement and maximum effort, are aspects of their identity that perpetuate the perfectionism culture demanded by the dance world $22,27,28$. Professionally, dancers need to be specialists about technical aspects and aesthetics come from their art and be psychological prepared to deal with the stress derived from lived situations in their training routine.

The physical shape is one of the greatest artistic demands in professional dance, contributing to the desire of a thinner body and the continuous self-dissatisfaction state, due a daily charge about the perfect body ${ }^{27}$. Evaluating the results pointed by studies included in this review singly is determined that professional dancers, regardless the chosen modality (classical ballet, contemporary, jazz) presents body image disturbance. Fact that corroborate with Ravaldi et al. ${ }^{11}$ that investigating gender aspects, body image and dancers eating disorders symptoms, found that the over concern with the body aesthetics is present in any artistic expression by the way of dance.

It is known that the body image disturb, marked by the negative self-evaluation of the individual related to its weight and body shape, is considered one of the main symptoms to the eating disorders development ${ }^{29}$. Professionals need an adequate aesthetic profile to be accepted in their areas of action, like models, dancer and athletes, show higher incidence in the body dissatisfaction cases, may trigger eating disorders, 30,31 . The studies $2^{10}$ and $5^{22}$ included in this review reinforced this Discovery, investigating Brazilian professional dancers and some eradicated in New York, from classic ballet and jazz, because, was identified the body image dissatisfaction associated with the eating disorders.

Therefore they presents an adequate body mass index, the studies on this review claim that professional dancers present themselves more satisfied with their body image when compared to others modalities professional dancers ${ }^{15}$, to the common population ${ }^{22}$, to students ${ }^{23}$ and to athletes ${ }^{24}$. Only one of the studies ${ }^{10}$, that investigated classical ballet and jazz professional dancers, identified that regardless the chosen modality, female professional dancers presents similar levels to body image dissatisfaction and distortion.

However, the study 1 results ${ }^{15}$ tell that when compared in two modalities, the contemporary professional dancers show more satisfied with their body image compared to the classic ballet professional dancers. Similar to the findings of Bolling and Pinheiro ${ }^{27}$ that refer the fact of the classical dancers weight on average 12\% to $15 \%$ less than the refered as normal values. In the other hand, modern dance companies allow themselves a larger shapes variety, making the that the values drop to $6 \% 27,32$

In function of the probable overweight, Bolling and Pinheiro ${ }^{27}$ repot in a systematic review elaborated about professional dancers and health that, dance academies use to realize regular weighing of their components, risking those individuals be excluded from roles or even from the dance company itself. Generally is possible to note the constant pressure related to the body image surrounded by the world of dance, especially when it is turned to the professional action environment. Actually seen as a national problem it can be observed the body image distortion cases in different contexts ${ }^{33}$. The importance of the thinness and the taken ideal appearance demand on the dance world could take to undesired pathologic behaviors and higher prevalence levels of eating disorders like anorexia and bulimics9,10,13,34,35.

In times of the "Perfect body" worship around hard beauty pattern demands is common that individuals, even euphoric ones, find itself dissatisfied with their bodies ${ }^{26,36,37}$. However, this high frequency of dissatisfaction among professional dancers is alarming, once that, to feel accepted in their environment, these have very thin bodies, turning the losing even more weight wish, a possibility to stimulate the practice of risk behaviors to eating disorders. Then, studies that propose to evaluate the body satisfaction in professional dancers groups of different modalities have a great relevance, because, they allow to investigate when the psychological aspects start to interfere on the body image perception of these individuals, enabling the wrong eating habits and health less prevention, specially alerting and warning the professionals that work with dance, like choreographers, directors, professors and physical educators. In addition, emphasize the importance of the original studies realization, in order to verify if these professional are able to identify the way how their dancers feel themselves, if these dancers are victimized or not by the relentless quest for the perfect body, many times influenced by the pressure from the dance professionals.

\section{CONCLUSIONS}

Analyzing the studies that compose this review, it's seen the prevalence of studies that cover the classic ballet modality, highlighting the gap to studies investigating other dance modalities, differing gender and dedication time to the modality a professional dancers.

Is conclusive that, even having thin bodies and normal body mass index, professional dancers, mostly classic ballet and jazz modalities, are dissatisfied with their bodies and wish to be thinner due to the strict aesthetic pattern demanded in this occupation. Considering then that, professional dancers compose a risk group to the incidence of hard disturbs together with disruption of eating behavior, bringing severe consequence to the professional dancers health.

It is considered from extremely relevance the realization of more researches in this area, due the lack of published studies related to body image and dance, even national or international level.

Understand the dancer in its singularity demands a greater knowledge even from the dance universe then its own work process. For that, more studies in order to comprehend and stimulate preventive actions are necessary, because, many times the wish of stay in this profession is, for many, stronger then the wish of being healthy.

All authors declare no potential conflict of interest related to this article.

AUTHORS' CONTRIBUTIONS: Cada autor contribuiu individual e significativamente para o desenvolvimento do manuscrito. AAC (0000-0002-0280-7567)* participou da escolha da temática, submissão, sumarização da produção científica nas bases de dados, análise e revisão dos estudos, descrição dos resultados, discussão de dados e conclusão. NMR (0000-0002-3925-9357)*, sumarização da produção científica nas bases de dados, análise e revisão dos estudos, descrição dos resultados, discussão de dados e revisão. APM (0000-0001-7469-1092)*, sumarização da produção científica nas bases de dados, análise e revisão dos estudos, descrição dos resultados, discussão de dados, revisão crítica do conteúdo intelectual. LB (0000-0003-4978-9703)* redação e discussão de dados, revisão e aprovação final da versão. ACAG (0000-0001-5167-2921)*, conceito intelectual, redação e revisão do manuscrito. *ORCID (Open Researcher and Contributor ID). 


\section{REFERENCES}

1. Claumann GS, Pereira EF, Inácio S, Santos MC, Martins AC, Pelegrini A. Satisfação com a imagem corporal em acadêmicos ingressantes em cursos de educação física. Rev Educ Fís/UEM. 2014;25(4):575-83.

2. Petroski EL, Pelegrini A, Glaner MF. Motivos e prevalência de insatisfação com a imagem corporal em adolescentes. Ciênc Saúde Coletiva. 2012;17(4):1071-7.

3. Alves D, Pinto M, Alves S, Mota A, Leirós V. Cultura e imagem corporal. Motricidade. 2009;5(1):1-20.

4. Wasylkiw L, Williamson ME. Actual reports and perceptions of body image concerns of young women and their friends. Sex Roles. 2013:68(3-4):239-51.

5. Zanetti T, Santonastaso P, Sgaravatti E, Degortes D, Favaro A. Clinical and temperamental correlates of body image disturbance in eating disorders. Eur Eat Disord Rev. 2013;21(1):32-7.

6. Tavares MCC. Imagem corporal e dança. Rev Conexões. 2001;1(6):10-22.

7. Tiggemann M, Slater A. A test of objectification theory in former dancers and non dancers. Psychol Women Q. 2001;25(1):57-64

8. Vieira JLL, Oliveira LP, Vieira LF, Vissoci JRN, Hoshino EF, Fernandes SL. Distúrbios de atitudes alimentares e sua relação com a distorção da auto-imagem corporal em atletas de judô do estado do Paraná. Rev. Educ. Fís/UEM. 2006;17(2):177-84.

9. Reis NM, Machado Z, Pelegrini A, Boing L, Monte FCS, Simas JPN, et al. A imagem corporal, estado nutricional e sintomas de transtornos alimentares em bailarinos. Rev Bras Ativ Fís Saúde. 2013;18(6):763-81.

10. Haas NA, Garcia ACD, Bertoletti J. Imagem corporal e bailarinas profissionais. Rev Bras Med Esporte. 2010;16(3):182-85.

11. Ravaldi C, Vannacci A, Bolognesi E, Mancini S, Faravelli C, Ricca V. Gender role, eating disorder symptoms, and body image concern in ballet dancers. J Psychosom Res. 2006;61(4):529-35.

12. Fração VB, Vaz MA, Ragasson CAP, Müller JP. Efeito do treinamento na aptidão física da bailarina clássica Movimento. 1999:11(2):3-15.

13. Ferreira A, Bergamin RA, Gonzaga TL. Correlação entre medidas antropométricas e aceitação pessoal da imagem corporal em bailarinas de dança moderna. Mov Percepção. 2008;9(12):42-51.

14. Ackard DM, Henderson JB, Wonderlich AL. The association between childhood dance participation and adult disordered eating related psychopathology. J. Psychosom. Res. 2004;57(5):485-90

15. Simas JPN, Macara A, Melo SIL. Imagem corporal e sua relação com peso e índice de massa corporal em bailarinos profissionais. Rev Bras Med Esporte. 2014;20(6):433-7.

16. Dotti A, Fioravanti M, Balotta M, Tozzi F, Cannella C, Lazzari R. Eating behavior of ballet dancers. Eat Weight Disord. 2002;7(1):60-7.

17. Ribeiro LG, Veiga GV. Imagem corporal e comportamentos de risco para transtornos alimentares em bailarinos profissionais. Rev Bras Med Esporte. 2010;16(2):99-102.

18. Damico J. Corpo a corpo com as jovens: grupos focais e análise de discurso na pesquisa em educação física. Movimento. 2006;12(2):35-67.

19. Liberati A, Altman DG, Tetzlaff J, Mulrow C, Gøtzsche PC, loannidis JP, et al. The PRISMA statement fo reporting systematic reviews and meta-analyses of studies that evaluate healthcare interventions: explanation and elaboration. BMJ. 2009;339:b2700.
20. Downs SH, Black N. The feasibility of creating a checklist for the assessment of the methodological quality both of randomised and non-randomised studies of health care interventions. J Epidemio Community Health. 1998;52(6):377-84.

21. Pollatoua E, Bakalib N, Theodorakisa Y, Goudasa M. Body image in female professional and amateu dancers. Res Dance Educ. 2010;11(2):131-7.

22. Nascimento AL, Luna JV, Fontenelle LF. Body dysmorphic disorder and eating disorders in elite professional female ballet dancers. Ann Clin Psychiatry. 2012;24(3):191-4.

23. Zoletić E, Duraković-Belko E. Body image distortion, perfectionism and eating disorder symptoms in risk group of female ballet dancers and models and in control group of female students. Psychiatr Danub. 2009;21(3):302-9.

24. Pierce EF, Daleng ML. Distortion of body image among elite female dancers. Percept Mot Skills. 1998;87(3 Pt 1):769-70.

25. Scagliusi FB, Alvarenga M, Polacow VO, Cordás TA, de Oliveira Queiroz GK, Coelho D, et al. Concurrent and discriminant validity of the Stunkard's figure rating scale adapted into Portuguese. Appetite. 2006;47(1):77-82

26. Damasceno VO, Lima JRP, Vianna JM, Vianna VRA, Novaes JS. Tipo físico ideal e satisfação com a imagem corporal de praticantes de caminhada. Rev Bras Med Esporte. 2005;11(3):181-86.

27. Bolling CS, Pinheiro TMM. Bailarinos profissionais e saúde: uma revisão de literatura. Rev Med Minas Gerais. 2010;20(2):S75-S83

28. Turner BS, Wainwright SP. Corps de ballet: the case of the injured ballet dancer. Sociol Health IIIn 2003;25(4):269-88.

29. Saikali CJ, Soubhia CS, Scalfaro BM, Cordás, TA. Imagem corporal nos transtornos alimentares. Rev Psiquiatr Clin. 2004;31(4):164-6.

30. Guimarães AD, Machado SP, França AKT, Calado IL. Transtornos alimentares e insatisfação com a imagem corporal em bailarinos. Rev Bras Med Esporte. 2014;20(4):267-71.

31. Stretanski MF, Weber GJ. Medical and rehabilitation issues in classical ballet. Am J Phys Med Rehabil 2002;81(5):383-91.

32. Assumpção ACR. O balé clássico e a dança contemporânea na formação humana: caminhos para a emancipação. Pensar Prát. 2003;6:1-19.

33. Secchi K, Camargo BV, Bertoldo RB. Percepção da imagem corporal e representações sociais do corpo. Psic Teor Pesq. 2009;25(2):229-36.

34. Silva CV, Fayh APT. Perda de peso e consumo de bebidas durante sessões de treinamento de ballet clássico. Rev Bras Ciênc Esporte. 2011;33(2):495-506.

35. Annus A, Smith GT. Learning experiences in dance class predict adult eating disturbance. Eur Eat Disord Rev. 2009:17(1):50-60.

36. Nicolaou M, Doak C, Dam Rv, Hosper K, Seidell J, Stronks K. Body size preference and body weight perception among two migrant groups of non-Western origin. Public Health Nutr. 2008;11(12):1332-41.

37. Kakeshita IS, de Sousa Almeida S. Relationship between body mass index and self-perception among university students. Rev Saude Publica. 2006;40(3):497-504. 